Anna MATUSZEWSKA

Matgorzata ODZIEMKOWSKA

Mateusz BEDNARSKI

Marcin Krzysztof WOJS

Jakub LASOCKI

\title{
Evaluation of the impact of the hydration degree of bioethanol on the operation parameters of the spark-ignition engine
}

The article presents an overview of methods for the production of bioethanol and the possibility of its use to power internal combustion engines. The effects of supplying spark-ignition engine with bioethanol having various degrees of hydration were examined experimentally on the engine dynamometer. The measurement results were referred to the anhydrous bioethanol, which is used widely as petrol biocomponent and compared in terms of the course of the pressure in the combustion chamber of the engine as well as engine performance parameters - torque and power. It was found that with the decrease in alcohol concentration, the performance of the sparkignition engine deteriorated. The reduction of in-cylinder pressure was proportional to the increase in the water content in the fuel. No significant changes in the general shape of in-cylinder pressure curves were observed. Engine torque and power decreased with an increase in the water content in the fuel, especially at high engine speed. It has been stated that supplying the engine with bioethanol containing up to $6 \%(\mathrm{v} / \mathrm{v})$ of water does not result in significant losses in engine performance.

Key words: bioethanol, water content, spark-ignition engine, engine performance

\section{Bioethanol production}

Bioethanol is an alcohol that is produced from many different types of carbohydrate-rich biomass, during alcoholic digestion. For its production are commonly used:

a) plants containing directly digesting sugars such as sucrose, glucose, fructose (e.g.: fruits, vegetables, sugar beets, sugar cane),

b) plants and wastes containing polysaccharides, degraded during hydrolysis into the fermentable mono- and disaccharides (e.g.: cereals, potatoes, industrial waste, lignocellulosic biomass).

The bioethanol production process is carried out in several stages depending on a type of the raw material involved and a degree of purification of the product (Fig. 1).

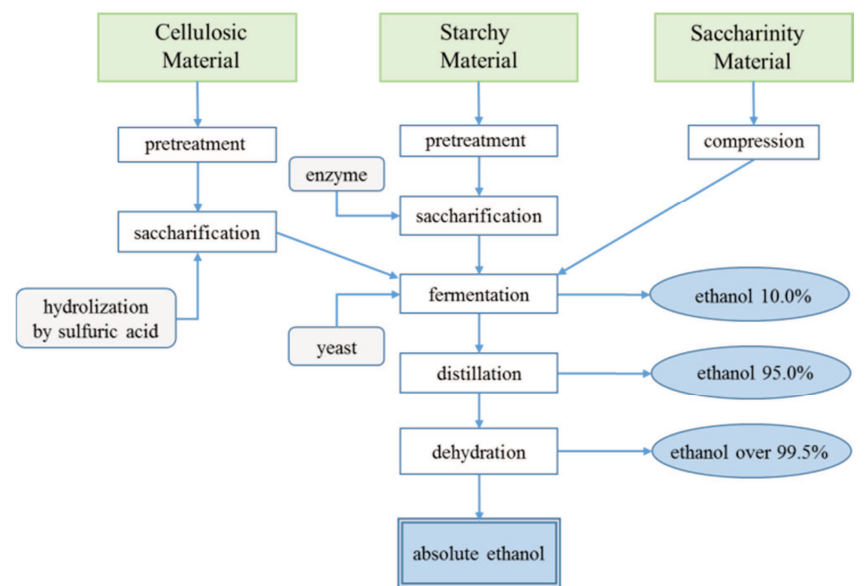

Fig. 1. Schema of bioethanol production processes depending on the raw material and the degree of purification of the product

There are four main stages in the ethanol production process: pretreatment, hydrolysis, fermentation and purification of the main product. The first stage is very important especially when the lignocellulosic raw material (extremely resistant to biodegradation) is used as a feedstock [16]. The appropriate methods used to pretreatment of the substrate can increase the efficiency of hydrolysis phase. Furthermore, such pretreatment limits the formation of toxic compounds that inhibit the metabolism of microorganisms involved in fermentation steps [4].

They are many methods of lignocellulosic biomass decomposition that break down the lignocellulosic fibers, reducing the degree of polymerization and crystallization of lignin-cellulose [23]. These methods can be divided into [7, 14, 15, 25]:

a) mechanical (the action of various kinds of shearing forces or changes in pressure are used, e.g. steam explosion),

b) non-mechanical: physical (e.g.: high or low temperature cellular destruction, treatment with detergents), chemical (oxidation processes, acid or alkaline hydrolysis) and biological (the use of special hydrolysis enzymes capable of degrading lignin and hemicellulose).

The disintegration of lignocellulosic biomass allows to hydrolyse of cellulose and hemicellulose into the simple sugars (C5 and C6) that are transformed into ethanol and carbon dioxide by Saccharomyces cerevisiae yeast or $Z y$ mamonas mobilis bacteria during alcoholic digestion $[2,6]$. Digestion is sensitive to changes of process conditions:

a) temperature (optimum range $30-38^{\circ} \mathrm{C}$ ),

b) acidity (optimum $\mathrm{pH}$ range $4.5-4.7$ ),

c) sugar concentration (typically in the range of $12-20 \%$ ),

d) oxygen content (a small amount of oxygen dissolved in the fermenting solution favorably affects the yeast growth rate and kinetics of the process),

e) alcohol concentration (more than $10-12 \%$ concentration of ethanol in digestion solution affects negatively on the growth of microorganisms and the process is discontinued [24]).

Besides ethanol, the post-fermentation mixture contains a lot of others compounds, for example: methyl esters, aldehydes (e.g. acetaldehyde), methanol, higher alcohols 
(amyl alcohol, propanol, isobutanol, so-called fusel oil), organic acids (acetic, butyric), glycerine, sulphur, not decomposed sugars, residues of substrates, microorganisms [10]. Moreover, the water content in this mixture is very high (above 80\%) and concentration process of ethanol up to $96 \%$ and higher requires a lot of energy and generates high costs [19]. As shown in Figure 2, the cost of ethanol dehydration above $70 \%$ rapidly grows.



Fig. 2. The cost of ethanol dehydration [21]

Ethanol has a high affinity to water and their mixtures form an azeotrope with a boiling point at $78.2^{\circ} \mathrm{C}$, which is lower than either of its components. Ethanol for fuel applications should be anhydrous. With the use of conventional distillation under atmospheric pressure it is impossible to obtain a product containing more than $80.4 \mathrm{~mol} \%$ of ethanol [18]. Therefore, to get an anhydrous ethanol the special processes are required. There are several such processes $[18,22]$ : chemical dehydration, dehydration by vacuum distillation, azeotropic distillation, diffusion distillation, extractive methods, membrane methods, adsorption methods. Some of these methods have been suppressed e.g. chemical dehydration due to high energy demand (high cost), or azeotropic distillation with benzene because of its carcinogenic effect. Others have some disadvantages like high cost connected with recycling big quantities of ethanol to the process (dehydration on molecular sieves), environmental pollution by losses of the azeotropic agent (azeotropic distillation) or high energy consumption (extractive distillation) $[17,18]$. In recent years more and more attention has been paid to the membrane technique, particularly to pervaporation. The separation is caused by differences in the solubility of particular components in the membrane (sorption) and differences in the diffusion rate through the membrane. Water permeates through the membrane, while dehydrated ethanol remains as the retentate.

\section{Bioethanol application for fuel purposes}

Biofuels are considered as good substitutes for fossil fuels. The use of them gives environmental and economic benefits. Bioethanol as a biofuel in the transport sector has gained interest all over the world. The use of bioethanol as a transportation fuel has been promoted in the USA, Brazil and Australia. The development of fuels contained bioethanol is promoted in the European Union as well. Detailed information on this subject can be found in the literature [3, $18,20]$.
Due to combustion and antiknock benefits, ethanol has been used as a fuel for many years. It can be used directly in an internal combustion engine or it can be blended with petrol or diesel. Pure alcohol needs some modifications in the area of engine design and fuel system [5], especially in the case of compression-ignition engines (initially, ethanol was not intended for combustion in this type of engine). Nowadays, mainly petrol with bioethanol admixture in various ratio has commercial importance. In the European Union bioethanol can be used as a $5 \%$ or $10 \%$ (by volume) blends with petrol without engine modification. After modification of spark-ignition engine, bioethanol can be used at higher levels, for example, E85 (a blended fuel of 85\% bioethanol and $15 \%$ petrol). In Brazil bioethanol is used as a pure fuel or as a mixture with petrol in the flexible range from $20 \%$ to $25 \%$ by volume $[3,11]$. Ethanol/petrol blend (so-called E10) is the standard fuel in the US market. By 2030 the bioethanol content in petrol will increase to $15 \%$ [12].

The chemical characteristic of ethyl alcohol is very different from that of hydrocarbon fuels. Typical properties of bioethanol in comparison with petrol are given in Table 1.

Table 1. Bioethanol and petrol characteristics [18]

\begin{tabular}{|l|c|c|}
\hline Characteristics & Bioethanol & Petrol \\
\hline Chemistry & $\mathrm{C}_{2} \mathrm{H}_{5} \mathrm{OH}$ & $\begin{array}{c}\text { Mixture of } \\
\text { hydrocarbons }\end{array}$ \\
\hline Density at $15^{\circ} \mathrm{C}\left[\mathrm{g} / \mathrm{cm}^{3}\right]$ & 0.785 & $0.72-0.75$ \\
\hline Distillation temperature $\left[{ }^{\circ} \mathrm{C}\right]$ & 78.4 & $32-210$ \\
\hline Flashpoint $\left[{ }^{\circ} \mathrm{C}\right]$ & 12 & 13 \\
\hline Flame temperature at $101.3 \mathrm{kPa}\left[{ }^{\circ} \mathrm{C}\right]$ & 478 & 392 \\
\hline Reid vapour pressure at $37.8^{\circ} \mathrm{C}[\mathrm{kPa}]$ & 17 & $35-60$ \\
\hline Research octane number & 111 & $91-100$ \\
\hline Motor octane number & 92 & $82-92$ \\
\hline $\begin{array}{l}\text { Net heat of combustion } \\
{\left[\mathrm{MJ} / \mathrm{kg}\left(\mathrm{MJ} / \mathrm{dm}{ }^{3}\right)\right]}\end{array}$ & $27.0(21.2)$ & $43.5(32.2)$ \\
\hline Heat of vaporization $[\mathrm{kJ} / \mathrm{kg}]$ & 900 & 400 \\
\hline Oxygen content $[\%, \mathrm{w} / \mathrm{w}]$ & 34.7 & 0 \\
\hline Stoichiometric air/fuel ratio $[\mathrm{w} / \mathrm{w}]$ & 8.97 & 14.6 \\
\hline Water solubility & $\infty$ & 0 \\
\hline Vapour flammability limits $[\%, \mathrm{v} / \mathrm{v}]$ & $3.5-15$ & $0.6-8$ \\
\hline Maximum flame speed $[\mathrm{m} / \mathrm{s}]$ & 0.40 & 0.33 \\
\hline
\end{tabular}

In comparison with petrol, bioethanol is characterized by higher research octane number, higher heat of vaporization, lower vapor pressure (due to strong intermolecular hydrogen bonding interaction between alcohol molecules [8], lower heat of combustion (per unit volume, bioethanol has $68 \%$ of petrol energy). Ethanol, unlike petrol, contains $35 \%(w / w)$ oxygen, so stoichiometric air/fuel ratio for this compound is lower that for fossil fuel [18]. The above mentioned properties affect engine performance and exhaust emissions. A higher octane number, wider flammability limits, higher flame speeds and higher heat of vaporization allow for a higher compression ratio and shorter burn time, which lead to theoretical efficiency advantages over petrol in an internal combustion engine [3]. High octane number prevents pre-ignition and it helps to run vehicle smoothly. On the other hand, the higher evaporation heat negatively influences the start of the cold engine. Low vapor pressure adversely influences cold start, too. The lower heating value of ethyl alcohol results in increased 
specific fuel consumption in comparison with petrol - a higher mass amount of alcohol is required per unit of output power [9].

Bioethanol, as oxygenate compound, reduces engine emissions. Leaning of fuel/air ratio causes the reduce nitrogen oxides and as well as carbon monoxide emissions [1, 18]. In comparison with petrol, alcohol combustion generates a higher volume of gaseous products, thus increasing cylinder pressure and the work done on the piston [9].

Disadvantages of bioethanol, besides the previously listed, are: its corrosiveness, toxicity to ecosystems, increase in exhaust emissions of acetaldehyde and increase in vapor pressure (and evaporative emissions), miscibility with water when blending with petrol. The addition of ethanol to hydrocarbons can significantly affect the properties of the resulting ethanol/petrol blend, among others: Reid vapor pressure and distillation characteristic. The increase in vapor pressure sharply rises until it reaches a maximum at approximately $4 \%-5 \%(\mathrm{v} / \mathrm{v})$ bioethanol and gradually decreases at levels higher than $4 \%-5 \%(\mathrm{v} / \mathrm{v})$. Whereas all levels of ethanol addition tend to lower the boiling temperatures in the mid-range and back-end of the distillation curve $[3,8,13]$.

Most of the published research papers are referred to mixtures of fossil fuels with bioethanol. There is lack of results concerning combustion of pure bioethanol with different water content. Therefore, it is difficult to assess the influence of water content in bioethanol on the engine characteristics. Such research may be important from the viewpoint of necessity of bioethanol dehydration, which is a costly process. Therefore, the purpose of the presented research was a determination of water content effect on the operation of a bioethanol-powered engine.

\section{Experiment and research results}

This work was aimed at determining the operating parameters of the spark-ignition engine powered by wateralcohol blends. The blends were prepared under laboratory conditions by adding of specified amount of water to dehydrated ethanol $(99.8 \%, \mathrm{v} / \mathrm{v})$. The real water content was estimated with the use of Karl-Fisher method. The obtained concentrations of ethanol and chosen physicochemical parameters of tested samples are shown in Table 2.

Table 2. Characterization of research samples of bioethanol

\begin{tabular}{|l|c|c|c|c|}
\hline \multirow{2}{*}{ Characteristics } & \multicolumn{4}{|c|}{ Bioethanol } \\
\cline { 2 - 5 } & 1 & 2 & 3 & 4 \\
\hline Ethyl alcohol content [\%, v/v] & 99.8 & 94.0 & 92.4 & 87.3 \\
\hline Water content $[\mathrm{mg} / \mathrm{kg}]$ & 0.3 & 5.8 & 7.4 & 12.5 \\
\hline Density at $15^{\circ} \mathrm{C}\left[\mathrm{g} / \mathrm{cm}^{3}\right]$ & 794.4 & 810.5 & 819.3 & 829.1 \\
\hline Vapor pressure $[\mathrm{kPa}]$ & 16.6 & 15.7 & 15.0 & 14.7 \\
\hline
\end{tabular}

The study was carried out on a single cylinder research engine with spark-ignition. It worked according to the speed characteristics, which allowed to determine the rotational speeds of the maximum power and torque. The engine capacity was $50 \mathrm{~cm}^{3}$ and the compression ratio was 1:4. Valve system made in pneumatic technology, a parameter of valve opening and closing time, fuel injection timing and length was electronically controlled. During testing, the torque generated by the engine, the rotational speed and the pressure in the combustion chamber were recorded. The test stand consisted of an electric brake, a spark-ignition engine, an indicator system, and a computer that recorded data. The block diagram of the test bench is shown in Fig. 3.

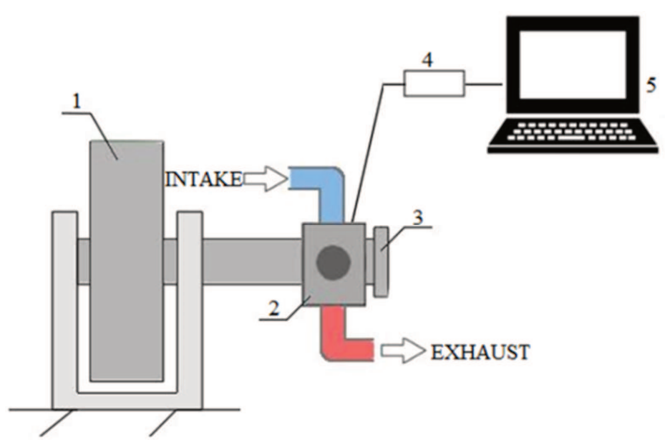

Fig. 3. Block diagram of the test stand 1 - engine brake, 2 - single cylinder spark-ignition engine, 3 - crank revolution angle recorder, 4 -indicator system, 5 - computer

Figure 4 shows the dependence of pressure in combustion chamber on a crank angle during supplying the engine with alcohol fuels with different water concentrations. This characteristic was created for the rotational speed of maximum power. Figures 5 and 6 present, respectively, the courses of engine torque and power as functions of engine speed for tested fuel samples.

As shown in Figure 4, it is clear that the increase in water concentration in ethanol causes the reduction of incylinder pressure during fuels combustion up to approximately $22 \%$ (from $9.6 \mathrm{MPa}$ for $99.8 \%$ ethanol content to $7.5 \mathrm{MPa}$ for $87.3 \%$ ethanol content). The observed reduction of in-cylinder pressure was proportional to the increase in the water content in the fuel. It should be noticed, that the pressure reduction affects power and torque of research engine. It should be emphasized that curves for $94.0 \%$ and $92,4 \%$ of bioethanol concentrations have a similar run from a $10^{\circ}$ crank angle.

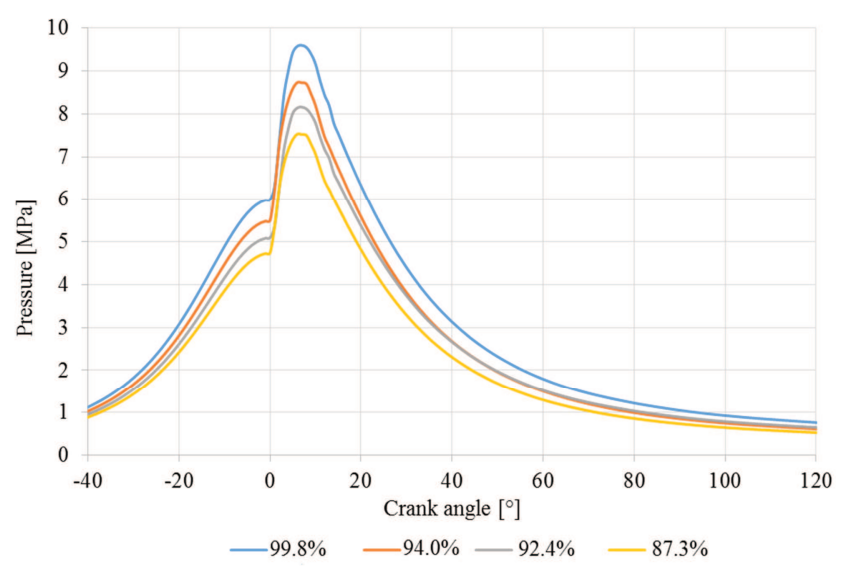

Fig. 4. Dependence of in-cylinder pressure on crank angle during combustion of the ethanol fuels with different content of water

The analysis of torque curves showed that observed changes are similar independently on water content in samples. The increase in engine speed caused the increase in torque. The maximum value of torque was at $2200 \mathrm{rpm}$ for all bioethanol concentrations. Then, the slight decrease in that parameter was observed. Higher content of water in 
fuels causes lowering of torque of the engine, especially in the range of higher engine speed. For example, at $1200 \mathrm{rpm}$ the torque changed from $0.45 \mathrm{Nm}$ to $0.32 \mathrm{Nm}$ and at 2200 rpm from $1.01 \mathrm{Nm}$ to $0.74 \mathrm{Nm}$, depending on the water concentrations (Fig. 5).

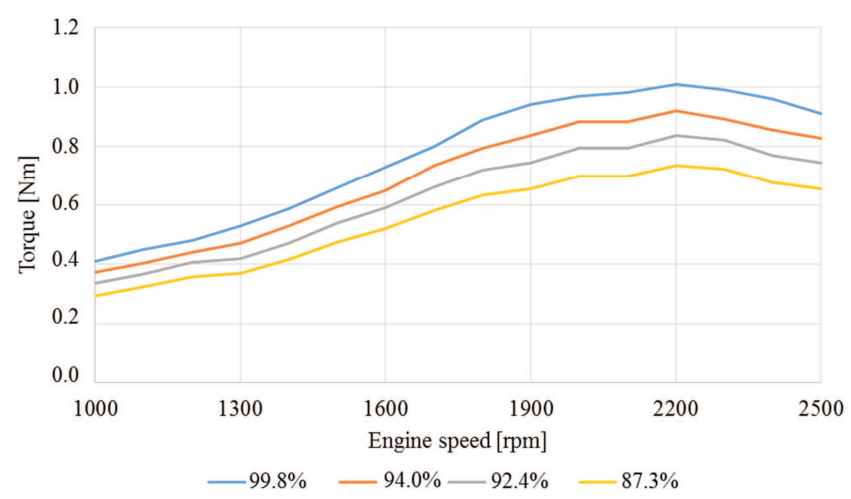

Fig. 5. Engine torque as a function of speed for the ethanol fuels with different content of water

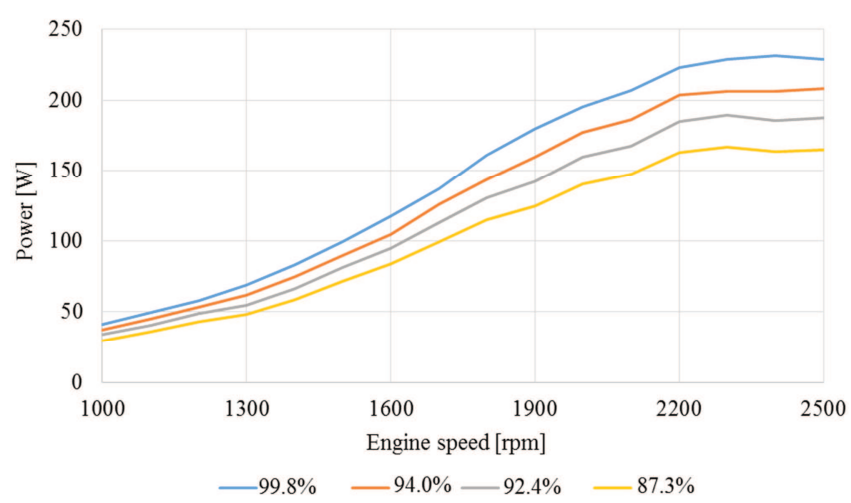

Fig. 6. Engine power as a function of speed for the ethanol fuels with different content of water

The influence of water content on the engine power was similar as it was observed in the case of parameter men- tioned above. The higher engine speed, the higher value of engine power for all tested fuels. However, water addition changes the maximum power point. The highest power $(232$ W) showed engine supplied with $99.8 \%$ bioethanol at 2400 rpm (Fig. 6). The lower content of ethanol in fuel caused a movement of maximum power point to the lower value of engine speed (2300 rpm). Additionally, it caused a decrease in the value of maximum power to $206 \mathrm{~W}, 190 \mathrm{~W}$ and $167 \mathrm{~W}$ for $94.0 \%, 92.4 \%$ and $87.3 \%$ bioethanol samples respectively. Compared to dehydrated ethanol, for samples containing water, the decrease in the power by $9 \%$ (for $94.0 \%$ ), $20 \%$ (for $92.4 \%$ ) and $30 \%$ (for $87.3 \%$ ) was observed at $2400 \mathrm{rpm}$.

Carried out research showed that it is possible to supply the engine with ethanol fuel containing up to $6 \%$ of water without major losses in the engine's operating parameters. This solution will reduce the financial costs and energy consumption connected with anhydrous ethanol production $[17,18]$.

In conclusion, the present study can be regarded as a preliminary work, that highlights some qualitative tendencies in terms of the relationship between water content in ethanol fuel and the engine performance.

\section{Summary}

Bioethanol can be a good substitute for fossil fuels, that use allows for environmental and economic benefits. It is primarily used as a biocomponent for gasoline. The ethanol used as a biofuel should be anhydrous, but the process of its concentration up to $96 \%(\mathrm{v} / \mathrm{v})$ and higher requires a lot of energy and generates high costs.

Research carried out by authors showed that with the increase of water in ethanol fuel up to $13 \%(\mathrm{v} / \mathrm{v})$ the decrease in power, pressure and torque of engine occurred. It has been stated that up to $6 \%(\mathrm{v} / \mathrm{v})$ of water concentration the losses in engine performance are not significant. It allows concluding that it is possible to supply the engine with the ethanol fuel containing water. This solution permits to reduce the costs of anhydrous ethanol production.

\section{Bibliography}

[1] AGARWAL, A.K. Biofuels (alcohols and biodiesel) applications as fuels for internal combustion engines. Progress in Energy and Combustion Science. 2007, 233, 233-271.

[2] BALAT, M., BALAT, H., ÖZ, C. Progress in bioethanol processing. Progress in Energy and Combustion Science. 2008, 34, 551-554.

[3] BALAT, M., BALAT, H. Recent trends in global production and utilization of bio-ethanol fuel. Applied Energy. 2009, 86, 2273-2282.

[4] BALAT, M. Production of bioethanol from lignocellulosic materials via biochemical pathway: A review. Energy Conversion and Management. 2011, 52, 858-875.

[5] BAYRAKTAR, H. Experimental and theoretical investigation of using gasoline-ethanol blends in spark-ignition engines. Renewable Energy. 2005, 30(11), 1733-1747.

[6] CHANDRA, R. et al. Methane production from lignocellulosic agricultural crop wastes: A review in context to second generation of biofuel production. Renewable and Sustainable Energy Reviews. 2012, 16, 1462-1476.

[7] CHANDRA, R., TAKEUCHI, H., HAGESAWA, T., Hydrothermal pretreatment of rice straw biomass: a potential and promising method for enhanced methane production. Applied Energy. 2012, 94, 129-140.

[8] CONCAWE REPORT 3/08 Guidelines for blending and handling motor gasoline containing up to $10 \% \mathrm{v} / \mathrm{v}$ ethanol. Available online: www.concawe.eu/publications/137/40/report-no-3-08 (accessed on 27.03.2016).

[9] COSTA, R.C., SODRE, J.R. Compression ratio effects on an ethanol/gasoline fuelled engine performance. Applied Thermal Engineering. 2011, 31, 278-283.

[10] CZUPRYŃSKI, B., KOTARSKA, K. Zanieczyszczenia chemiczne spirytusów surowych związkami karbonylowym. Inżynieria i Aparatura Chemiczna. 2009, 48, 31-32.

[11] DE FREITAS, L.C., KANEKO, S., Ethanol demand under the flex-fuel technology regime in Brazil. Energy Economics. 2011, 33, 1146-1154. 
[12] European Biofuels technology Platform available online: www.biofuelstp.eu/bioethanol.html (accessed on 27.03 2016).

[13] FRENCH, R., MALONE, P. Phase equilibria of ethanol fuel blends. Fluid Phase Equilibria. 2005, 228-229, 27-40.

[14] HATAKKA, A. Lignin-modifying enzymes from selected white-rot fungi: production and role from in lignin degradation. FEMS Microbiology Reviews. 1994, 13, 125-135.

[15] HENRICS, A.T.W.M., ZEEMAN, G. Pretreatments to enhance the digestibility of lignocellulosic biomass. Bioresource Technology. 2009, 100, 10-18.

[16] JORGENSEN, H., KRISTENSEN, J.B., FELBY, C. Enzymatic conversion of lignocellulose into fermentable sugars: challenges and opportunities. Journal of Biofuels, Bioproducts and Biorafinering. 2007, 1(2), 119-134.

[17] KAMINSKI, W., MARSZALEK, J., CIOLKOWSKA, A. Renewable energy source-dehydrated ethanol. Chemical Engineering Journal. 2008, 135, 95-102.

[18] KUMAR, S., SINGH, N., PRASAD, R. Anhydrous ethanol: A renewable source of energy. Renewable and Sustainable Energy Reviews. 2010, 14, 1830-1844.

[19] LEJA, K, LEWANDOWICZ, G., GRAJEK, G., Produkcja bioetanolu z surowców celulozowych. Biotechnologia. 2009, 87, 88-101.

\footnotetext{
Marlena Owczuk, MEng. - Department of Fuels and Renewable Energy, Automotive Industry Institute in Warsaw.

e-mail:M.Owczuk@pimot.eu
}



Anna Matuszewska, DEng. - Department of Fuels and Renewable Energy, Automotive Industry Institute and Cardinal Stefan Wyszynski University.

e-mail:A.Matuszewska@pimot.eu

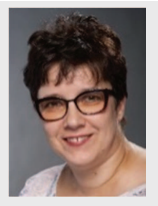

Małgorzata Odziemkowska, MEng. - Department of Fuels and Renewable Energy, Automotive Industry Institute in Warsaw.

e-mail:M.Odziemkowska@pimot.eu
[20] ODZIEMKOWSKA, M., MATUSZEWSKA, A., CZARNOCKA, J. Bioethanol as a fuel for compression-ignition engines. Applied Energy. 2016, 184, 1264-1272.

[21] OKABE, K., et al. Energy and cost evaluation for the concentration and dehydration process of bioethanol by zeolite membranes. Kagaku Kogaku Ronbunshu. 2010, 36, 486493.

[22] RAKOCZY, J., KUPIEC, K., BŁĄK, A., LARWA, T. Usuwanie wody ze spirytusu gorzelnianego w celu otrzymania bioetanolu paliwowego. Czasopismo Techniczne Chemia. 2008, 1, 115-124.

[23] SUN, Y., CHENG, J., Hydrolysis of lignocellulosic material for ethanol production: a review. Bioresource Technology. 2002, 83, 1-11.

[24] SZYMCZYK, E. Stan badań i perspektywy wdrożeń technologii do produkcji bioetanolu paliwowego z surowców lignocelulozowych. Praca dyplomowa. Kraków 2008/2009.

[25] ZHANG, B., SHAHBAZI, A. Recent developments in pretreatment technologies for production of lignocellulosic biofuels. Journal of Petroleum \& Environmental Biotechnology. 2011, 2(2), 1-8.

Marcin Krzysztof Wojs, DEng. - Faculty of Automotive and Construction Machinery Engineering at Warsaw University of Technology.

e-mail:Marcin.Wojs@simr.pw.edu.pl



Mateusz Bednarski, MEng. - Institute of Vehicles, Department of Combustion Engines, Warsaw University of Technology.

e-mail:Mateusz.Bednarski@simr.pw.edu.pl

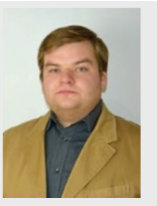

Jakub Lasocki, DEng. - Faculty of Automotive and Construction Machinery Engineering at Warsaw University of Technology.

e-mail: J.Lasocki@simr.pw.edu.pl 